University of Nebraska - Lincoln

DigitalCommons@University of Nebraska - Lincoln

November 2021

\title{
Utilization of Electronic Resources by Library Users In Kwara State University, Nigeria
}

Abdrahman Atanda Moustapha

Kwara State University, abdrahman.moustapha@kwasu.edu.ng

Follow this and additional works at: https://digitalcommons.unl.edu/libphilprac

Moustapha, Abdrahman Atanda, "Utilization of Electronic Resources by Library Users In Kwara State University, Nigeria" (2021). Library Philosophy and Practice (e-journal). 6379.

https://digitalcommons.unl.edu/libphilprac/6379 


\title{
Utilization of Electronic Resources by Library Users In Kwara State University, Nigeria
}

\author{
BY \\ Abdrahman Atanda Moustapha (CLN, NLA)
}

Associate Librarian

Ilorin Central Mosque Library

Email: ismuljalallah@gmail.com

Phone: +2348033660831 


\section{ABSTRACT}

This study investigated utilization of electronic resources by the users in the Kwara State University Library, Nigeria. Cross-sectional survey research design was adopted for the study. The population of the study comprised of 3,670 registered users with the library and a sample of 367 was selected using simple random sampling technique. Questionnaire was used as the instrument for data collection. 367 copies of the questionnaire were administered while 345 were returned which used for the study. The data were analyzed using descriptive statistics for the research questions. The findings showed that all the types of electronic resources listed in the study are available with electronic books having the highest responses. The study found out that there is no significant difference in the extent to which users utilize ERs. The study recommended among others that since electronic books are available in the university library, the University library management should intensify the availability of other types especially CD-ROMs and DVD by supplying more.

Keywords: Electronic Resources, University Library, Users. 


\section{Introduction}

In modern times, the content of libraries is not restricted to physical formats such as books, magazines or journals. Libraries are now shifting from traditional printed resources to the use of electronic resources and other electronic-driven services (Nnadozie and Nwosu, 2016; Okazie, 2016). However, the use of electronic resources does not take the place of printed resources but facilitates it through access to large stock of Library materials (Okazie, 2016). The changes that have occurred in the world of ICT are what have shifted the content of libraries' resources from printed information to online information resources (Israel and Edesire, 2016). They also make electronic sources of information available to users because e-learning is giving new dimension in learning and hence affecting education in many ways (Bajpaiet al. 2016). Besides, following technological revolution, libraries do not need to be in a physical space to be able to provide information to its users. The main reason is that ICT is contributing significantly towards the removal of geographical barriers across the globe (Prakash, 2017). Libraries have also formed cooperation among themselves to facilitate resources sharing.

Moreover, the use of information technology in libraries is not only a choice but inevitable in the era of information technology (Dar et al. 2017). Libraries are gradually establishing resource sharing to reduce cost and meet the requirements of user demands (Prakash, 2017). This establishes a direct link between libraries and information services with joint influence on knowledge discovery and dissemination in the digital era (Atram, 2017). The use of information technology has created advance contribution in the information technology field which has improved the services of libraries significantly. Besides, the application of ICT in libraries is 
providing opportunities to users to access and utilize both online resources and other services effectively (Saikia and Gohain, 2013; Atram, 2017; Prakash, 2017).

\section{Literature Review}

Electronic resources are digitized information, facilitated by computers, network connectivity, electricity and other peripheral components and most importantly human beings. It comes in different formats including text, videos, audio, graphics, tables, pictures, etc.

Electronic Resources are information resources that can be accessed electronically via the Internet or digital media. Electronic resources according to Bankole, Ajiboye and Otunla (2015) consists of information resources provided in electronic formats such as internet, CDROM databases, e-books e-journals, Online database, Online Public Access Catalogues, and other computer-based electronic networks.

According to Yakubu and Olatoye (2015) electronic resources are the information on devices such as net, hard disc, flash drive and CD ROMS. It could be in form of database application created for a particular organization that manages data and allows easy access, fast storage and retrieval of that data. However, the magnitude of the usage of these e-resources has been split between positive and negative results. Whereas some current studies such as Verma and Laltlanmawii (2016), Mollel, (2016), Alphonce (2015) indicate insignificant use of the eresources subscribed to, others such as Kumar (2016), Mammo and Ngulube (2015), Singh (2013 found significant use of these resources by users communities. Singh (2013) presents that 100 percent of users at the University of Jamia Millia Islamia used e-resources. In the same vein, Uplaonkar and Keshva (2013) observe that college members at Nijalingappa Medical College were positive towards the use of e-resources for studying, research and teaching, specifically online databases such Emerald, EBSCO, and PROQUEST were frequently utilized by college 
members and researchers generally. Also, e-resources are easily accessible in the remote areas (Khan, 2016). According to Kumar (2016), the use of e-resources enhances communication, career development, teaching and research in addition to providing subject-specific and updated information.

\section{Type of Electronic Resources}

The emergence of technological advancement has made users to be more diverse in information seeking; Kwara state university library are challenged to meet these needs by providing appropriate electronic resources. The following are types of ERs usually found in Kwara State University library.

\section{Electronic Books}

Electronic books (e-books) according to Johnson et al. (2012) are books that are provided in a digital format for checkout or use via an internet browser, a computer, or another electronic device like an e-book Reader. An e-book can take the form of a single monograph or a multivolume set of books in a digital format that allows for viewing on various types of monitors, devices, and personal computers. One area that is well recognized as benefiting from e-books is distance learning. Online education makes higher education more affordable and accessible; the number of students enrolling for online education programs is constantly increasing. Students can complete or advance their education while they work (Minčić-Obradović, 2011). Questa is one example of companies that offer web access to e-books.

\section{Electronic Journals}

Electronic journals (e-journals) which have undoubtedly become one of the most used technological innovations form a major part of these electronic resources. Electronic journals (ejournals) according to Johnson, Evensen, Gelgand, Lammers, Sipe and Zilper (2012) are journals 
provided in a digital format for access via an internet browser, a computer or other electronic device. Electronic journals provide efficient access to information and, thus they are easy to distribute to library patrons than traditional print. Journals made available in electronic form have now become an accepted norm for many academic institutions in the world. It is therefore the responsibility of an academic institution to make these

\section{Online Databases}

The most effective way to provide access to electronic books/journals in university libraries is through subscription to online databases which can be accessed through the internet. Online databases are a collection of electronic sources (e-journals/e-books) by publishers from various fields and disciplines (Afolabi, 2007 cited in Dongardive, 2015). Online databases are essential in contemporary research processes in university libraries. Some of these databases include:

Health Network Access Research Initiative (HINARI), Access to Global Online Research in Agriculture (AGORA), Online Access to Research in the Environment (OARE) etc. Access to these databases provides users with scholarly articles in their respective fields of study.

\section{Compact Disc-Read Only Memory (CD-ROM) Databases}

CD-ROM databases allow users access to relevant databases without vigorous internet connectivity in libraries. A CD-ROM is an e-resource format that contains up to 650-900 MegaBytes (MB) of information on a single-sided and single-layered optical disc (Johnson et al., 2012). It is a CD that can be read by a computer with an optical drive. No information is lost if there is power cut. It is possible to record on CD-ROM text, figures, graphs and digital pictures. The CD-ROM technology has dominated a lot of discussion in library and information service. This is due to its enormous advantages. 


\section{Institutional Repository}

An institutional repository is a web - based database of scholarly material which is institutionally defined, cumulative and perpetual, and openly accessible to members of the institution's community (Mark Ware Consulting Ltd., 2014). Al - Suqri, Lillard\& Al - Saleem (2014). Institutional repositories thus mostly contain the intellectual works of faculty, students and alumni, digitized archival materials, as well as records of ongoing scholarly activities and events of the institution itself.

\section{Availability}

Generally, the majority of academics and researchers are aware of different kinds of e-resources available (see, for example, Kumar, 2016; Mammo \& Ngulube, 2015) such as e-journals, books, theses, articles, dissertations, dictionaries, encyclopedias, databases, newspapers, magazine, email, internet, OPAC and CD-ROM (Verma \& Laltlanmawii, 2016; and Kumar, 2016.

Since the early 1990s, several initiatives aimed to increase the availability of e-resources have resulted in a significant increase in the number of African institutions subscribing to these eresources. In this regard, important initiatives include the International Network for the Availability of Scientific Publications (INASP)‘s PERI (Programme for Enhancement of Research Information), African Journal Online (AJOL), and JSTOR schemes funded by commercial publishers and the United Nations (UN) namely HINARI, AGORA, and OARE (Alphonce, 2015; Msagati, 2014).On the contrary view Alhassan and Macaulay (2015) in a study, availability and utilization of electronic resources by University students in Niger state, shows that electronic resources like the internet, e-mail, online databases, electronic databases 
and electronic journals were highly used by the respondents in the two universities, while others like CD-ROM databases, electronic journals, Online Public Access Catalogue (OPAC) and electronic books were rarely used.

\section{Utilization of Electronic Resources}

Macaulay (2015) in a study, availability and utilization of electronic resources by University students in Niger state, shows that electronic resources like the internet, e-mail, online databases, electronic databases and electronic journals were highly used by the respondents in the two universities, while others like CD-ROM databases, electronic journals, Online Public Access Catalogue (OPAC) and electronic books were rarely used. The study also reveals that the undergraduate students used the electronic resources for various purposes, such as online application/registration, research, communication with friends and colleagues, sourcing materials for project writing, completing assignments, and for other personal purposes.

However, the magnitude of the usage of these e-resources has been split between positive and negative results. Whereas some current studies such as Verma and Laltlanmawii (2016), Mollel, (2016), Alphonce (2015) and Okiki (2012) indicate insignificant use of the e-resources subscribed to, others such as Kumar (2016), Mammo and Ngulube (2015), Singh (2013 found significant use of these resources by users communities. Singh (2013) presents that 100 percent of users at the University of Jamia Millia Islamia used e-resources. In the same vein, Uplaonkar and Keshva (2013) observe that college members at Nijalingappa Medical College were positive towards the use of e-resources for studying, research and teaching, specifically online databases such Emerald, EBSCO, and PROQUEST were frequently utilized by college members and researchers generally. Also, e-resources are easily accessible in the remote areas (Khan, 2016). According to Kumar (2016), the use of e-resources enhances communication, career 
development, teaching and research in addition to providing subject-specific and updated information. Oyedapo and Ojo (2013) carried out a study on the use of electronic resources at Obafemi Awolowo University, Nigeria and under-utilization of electronic resources was observed. The major reason for the under-utilization of electronic resources was poor searching skills. On the contrary view Alhassan and Macaulay (2015) in a study, availability and utilization of electronic resources by University students in Niger state, shows that electronic resources like the internet, e-mail, online databases, electronic databases and electronic journals were highly used by the respondents in the two universities, while others like CD-ROM databases, electronic journals, Online Public Access Catalogue (OPAC) and electronic books were rarely used.

\section{Challenges Faced in the Use of Electronic Resources}

There are several challenges facing the use of electronic resources. Mammo and Ngulube (2015) opined that low bandwidth and unclear institutional policy constitute potential problems that are likely to hamper such information access and eventual use.

Bhatt and Rana (2011) identified that the most common problems with e-resources are low speed connectivity, lack of awareness about statutory provision for accessing e-resources by the institutions, technical problems, unavailability of sufficient e-resources, doubts in permanency, high purchase price and lack of legal provision. A similar study by Egberogbe (2011) revealed that some of the factors hindering the use of e- resources in university libraries include; lack of strategic planning, adequate or reliable funding, lack of use of internet to provide information services to users and a lack of consistent training for users in new ICT services. Several studies have identified a number of problems associated with the use of ERs. These problems range from lack of or inadequate resources, mainly computers, and poor internet connectivity, inappropriate usage to lack of appropriate skills among users. In the study of 
Kwafoa, Osman and Afful-Arthur (2014) found that the challenges facing faculty members in using online academic resources are charges to access ERs (18.31\%), lack of proper guidance $(19.31 \%)$, slow nature of the internet $(35.92 \%)$ and Lack of knowledge about tools and techniques used for searching and retrieving ERs (8.45\%). This meant that there is the need to intensify awareness creation and education on the accessibility and usage of the library's online academic databases. Alhassan and Macaulay (2015) reported in their study that, limited access to computer terminals, lack of IT knowledge to effectively utilize the services, non-assistance from library staff to facilitate easy access and network failure were some of the hindrances to effective use of ERs in University libraries. Oyedapo and Ojo (2013) carried out a study on the use of electronic resources at Obafemi Awolowo University, Nigeria and under-utilization of electronic resources was observed. The major reason for the under-utilization of electronic resources was poor searching skills. BaroEndouware and Ubogu (2011) also studied the awareness and use of online information resources by medical students at Delta State University in Nigeria and found that scholarly electronic journal databases were under-utilized. Users cited lack of awareness of the existing resources as the primary problem they had. Okello and Magara (2008) supported this notion of under-utilization and found that the obstacle to access and utilization of electronic journals by Makerere students in Uganda as well as students in other higher learning institutions was lack of awareness about the resources.

Undergraduate students used ERs for different purposes. Kumar and Kumar (2008) in their study discovered that the purpose of accessing electronic information resources is to support learning and also to write project work. Ansari and Zuberi (2010) added that many students use eresources for research. Others also use them to perform assignments, prepare for examinations and to gain subject knowledge. Similarly, Cothran (2011) asserted that graduate students use 
Google Scholar more since they find it easy to learn and easy to navigate. Also, the design and interface of search engines are user-friendly and it is a useful resource for their research. Emerole and Ogugua (2007) in their study of library use study found out that there is low patronage of library services especially in the area of use of EIR as many users have not fully realized the potentials of the library in this information age.

\section{Statement of the Problem}

Electronic resources have brought new innovations in librarianship where library users can now access information and resources beyond the physical library space. According to Sharma (2009) the advent of information and communication technologies such as the Internet and the web, electronic resources have brought a widely accepted scholarly resources for the library users. Electronic Resources (ERs) play vital roles in teaching and learning process in the academic environment and provide assistance to users. They enable users have access to first-hand information characterized by being timely, current, easy to access and, even from remote places (Ukachi, 2013). A lot of money is being invested to procure and maintain ERs in university libraries. However, observation of the researchers reveals under-utilization of ERs. This concurs with the assertion of Ferdinand, Eghworo, and Paul (2015) and Adeniran (2013) both reported low utilization of ERs by undergraduate students at the Federal University of Petroleum Resources Effurun and Redeemer's University, Nigeria respectively. It is therefore on this basis that this study is set to investigate utilization of electronic resources in the Kwara state university library. 


\section{Research Questions}

The study answered the following questions

1. What types of electronic resources are available for users in Kwara state university library?

2. To what extent do users utilize electronic resources in Kwara state university library?

3. What are the challenges faced in accessing electronic resources in Kwara state university library?

\section{Research Hypothesis}

HO. There is no significant difference in the extent to which users utilize ERs in Kwara state university library.

\section{Methodology}

The study adopted cross-sectional survey research design. A total of 3670 registered users comprised the population for the study and samples of 367 users were selected using simple random sampling technique. Questionnaire was the instrument used for data collection and was validated by lecturers in the department of library and information science, Kwara state university. Descriptive statistic such as graphs and tables were used to analyze data that relate to the research questions and t-test was used to test the formulated null hypothesis. A total of 367 copies of the questionnaire were distributed and 345 (94\%) copies were returned. The response rate of $94 \%$ was considered adequate for the study. 


\section{Data Analysis and Interpretation}

Data were analyzed and results were presented in line with the study research questions and hypothesis.

Research Question One: What types of electronic resources are available for users in Kwara State university library?

Table 1: Types of ERs for Users in Kwara State University Library

\begin{tabular}{|l|l|l|}
\hline Electronic Resources & \multicolumn{2}{|c|}{ Response Received } \\
\hline & Available (\%) & Not Available (c) \\
\hline Institutional Repository & $162(47 \%)$ & $183(53 \%)$ \\
\hline E - Journals/ Magazines & $162(47 \%)$ & $183(53 \%)$ \\
\hline E - Newspaper & $254(74 \%)$ & $91(26 \%)$ \\
\hline Online - Databases & $136(39 \%)$ & $209(61 \%)$ \\
\hline CD - ROMS & $125(36 \%)$ & $220(64 \%)$ \\
\hline E - Books & $263(76 \%)$ & $82(24 \%)$ \\
\hline DVD & $90(26 \%)$ & $255(74 \%)$ \\
\hline
\end{tabular}




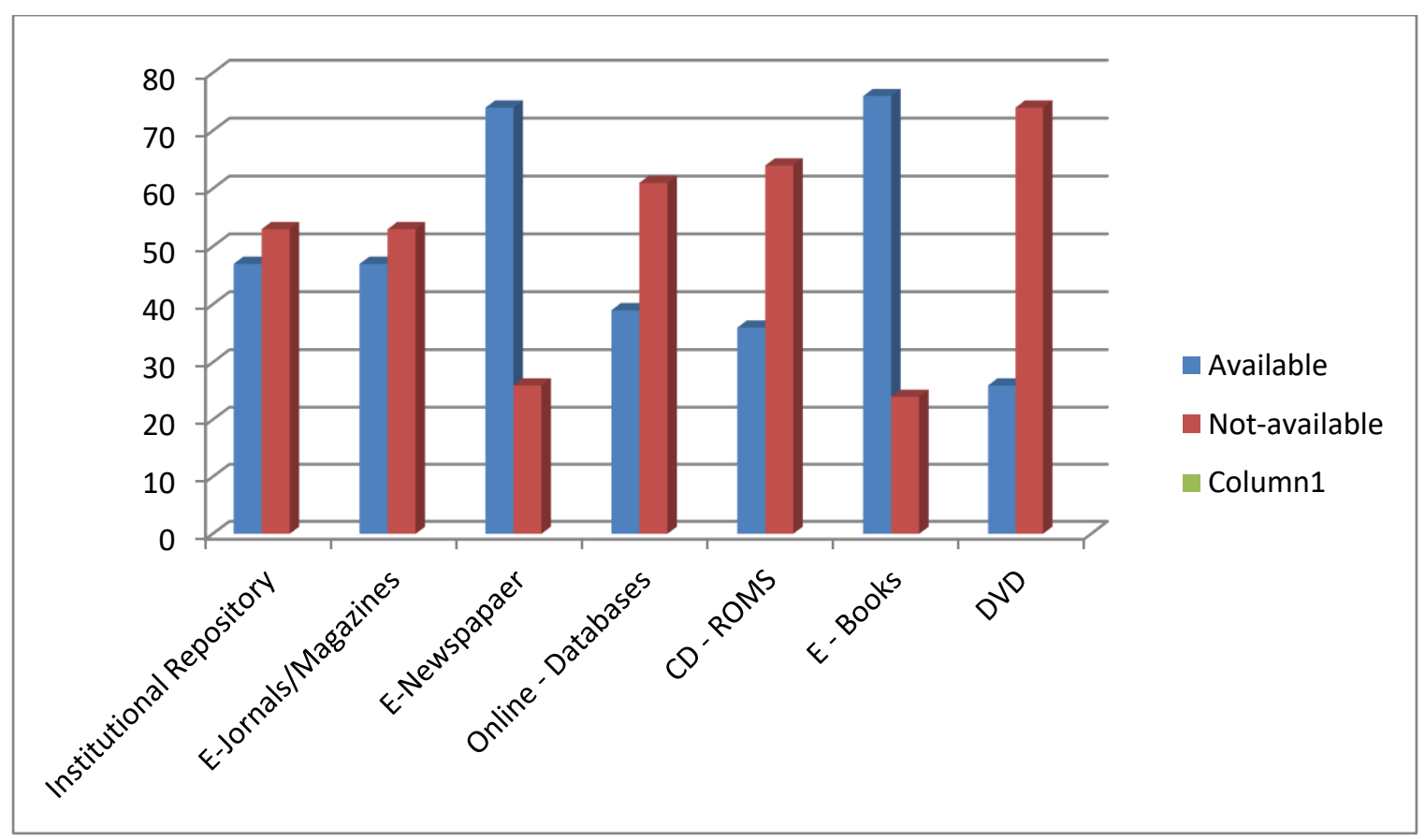

Table 1 presented the types of electronic resources in the Kwara State university library. The Table has shown that the electronic books with respondent of $76 \%$ have the highest response rate more than any others, E-newspapers have 74\%, E-journals/E-magazines have 47\%,Institutional Repository have 47\%, CD-ROMs have 36\%, Online Databases 39\% and DVDs with total respondent of $26 \%$ have the lowest response rate.

From the total respondent of electronic books with the $76 \%$ have the highest while DVD with the total respondent of $26 \%$ has the lowest response.

Research Question Two: To what extent do the users utilize electronic resources in Kwara State university library?

For convenience and ease of data presentation and analysis, the five points Likert Scale were collapsed to 3 points. They are:

Highly Utilize (HU), Rarely Utilize (RU) and Undecided (U).

This is presented in table 2 .

Table 2: Extent to which Users Utilized ERs in Kwara State University Library 


\begin{tabular}{|l|l|l|l|}
\hline Electronic Resources & \multicolumn{3}{|c|}{ Response Received } \\
\hline & HU (\%) & RU (\%) & U (\%) \\
\hline Institutional Repository & $255(74 \%)$ & $85(25 \%)$ & $5(1 \%)$ \\
\hline E - Journals/ Magazines & $215(62 \%)$ & $110(32 \%)$ & $20(6 \%)$ \\
\hline E - Newspaper & $247(72 \%)$ & $90(26 \%)$ & $8(2 \%)$ \\
\hline Online - Databases & $106(31 \%)$ & $210(61 \%)$ & $29(8 \%)$ \\
\hline CD - ROMS & $95(28 \%)$ & $111(32 \%)$ & $139(40 \%)$ \\
\hline E - Books & $147(43 \%)$ & $188(54 \%)$ & $10(3 \%)$ \\
\hline DVD & $68(20 \%)$ & $97(28 \%)$ & $180(52 \%)$ \\
\hline
\end{tabular}

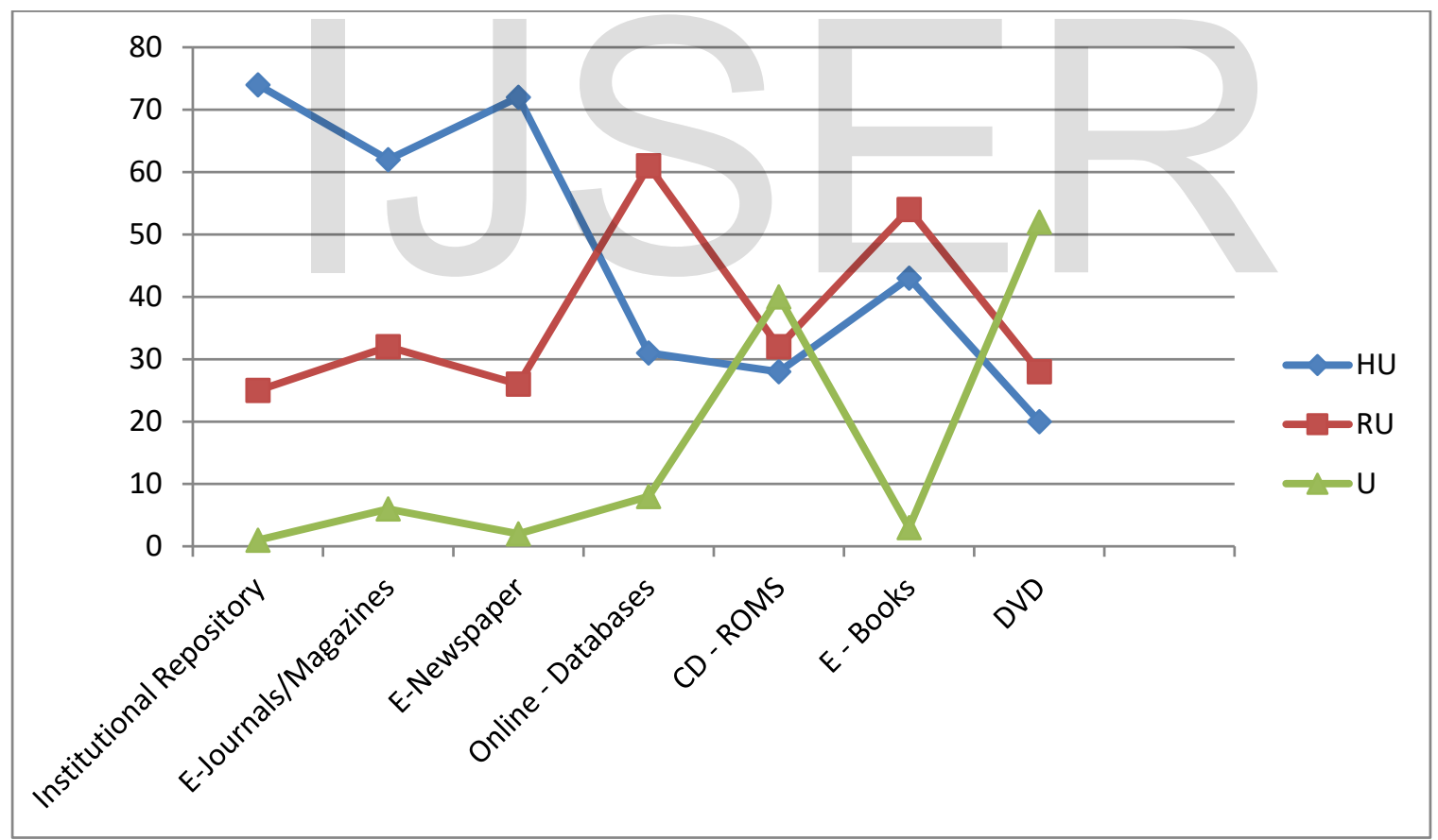


Table 2 indicated that majority of the respondents in Kwara State university library showed that the Institutional Repository with the respondent of $74 \%$ have the highest responses, E Newspaper have 72\%, e - books (43\%), E-journals/magazines (62\%), Bibliographic Databases $31 \%$, CD - ROMS $28 \%$ while DVD with the respondent of $20 \%$ have the lowest responses.

From the total respondent of Institutional Repository with the $74 \%$ have the highest while DVD with the total respondent of $26 \%$ has the lowest response.

Research Question Three: What are the challenges faced in accessing electronic resources in Kwara State university library?

Table 3: Challenges Faced in the Utilization of ERs in the Kwara State University Library

\begin{tabular}{|l|l|l|}
\hline Hindrances & Agreed (\%) & Not Agreed (\%) \\
\hline Inadequate computers in the library & $60(17 \%)$ & $285(83 \%)$ \\
\hline Lack of information on how to use E - resources & $235(68 \%)$ & $110(32 \%)$ \\
\hline Insufficient search skills & $203(59 \%)$ & $142(41 \%)$ \\
\hline Poor internet connectivity & $125(36 \%)$ & $220(64 \%)$ \\
\hline Non-availability of required information & $250(72 \%)$ & $95(28 \%)$ \\
\hline Power outages & $290(84 \%)$ & $55(18 \%)$ \\
\hline Limited subscribed titles & $130(38 \%)$ & $215(62 \%)$ \\
\hline
\end{tabular}




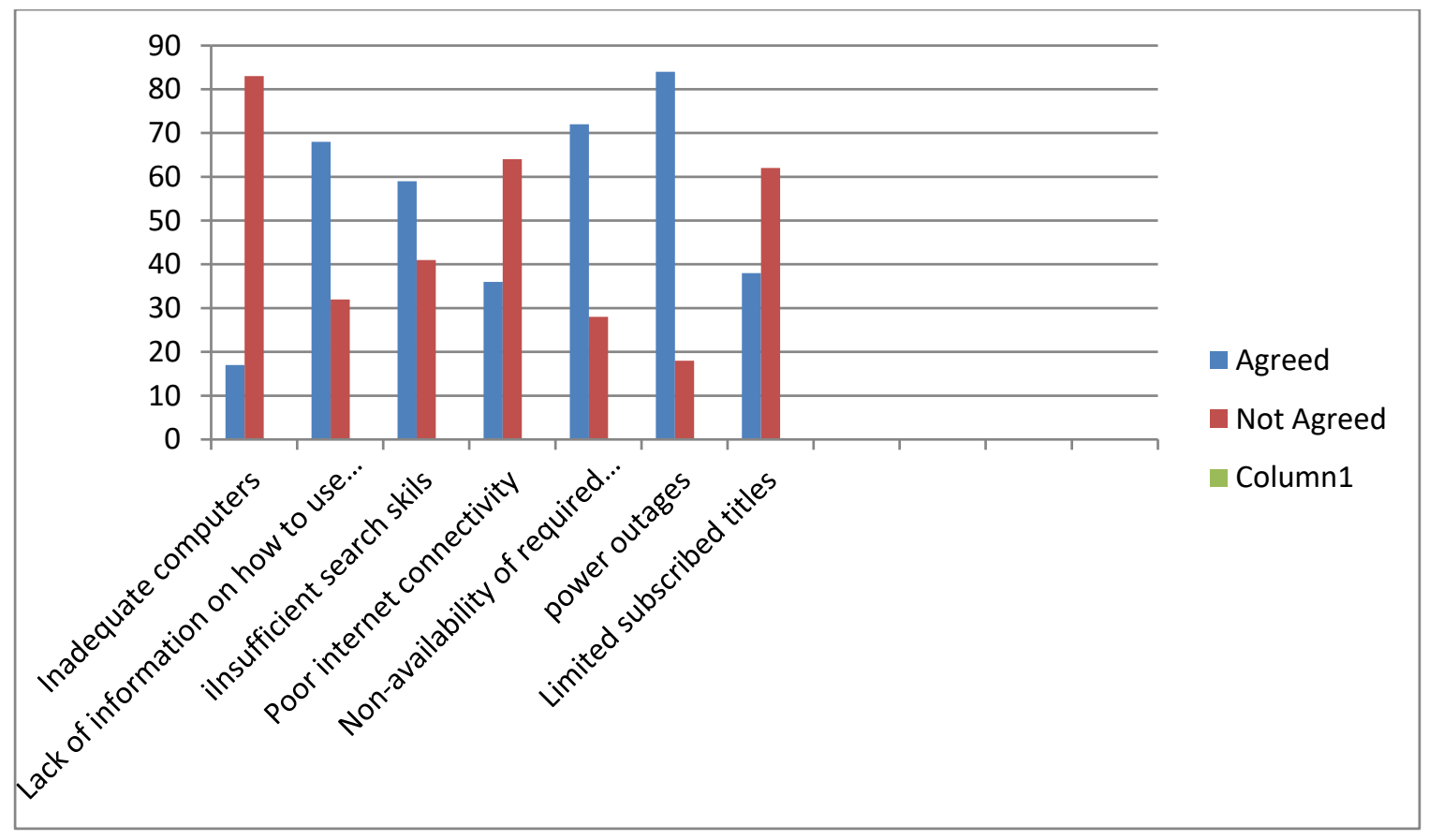

Table 3 indicates that majority of the respondents in Kwara State university library showed that the challenges the users encountered most in accessing electronic resources were Power outrages with the respondent of $84 \%$ were the major challenges, Non-availability of required information have $72 \%$, Lack of information on how to use E - resources have $68 \%$, Insufficient search skills have $59 \%$, Limited subscribed titles have $38 \%$, Poor internet connectivity have $36 \%$ while inadequate computers in the library $17 \%$ have the lowest responses.

From the total respondent of Power outrage with the respondent of $84 \%$ have the highest while inadequate computers in the library with the total respondent of $17 \%$ have the lowest response. 


\section{Data Analysis and Interpretation}

Data were analyzed and results were presented in line with the study research questions and hypothesis.

Research Question One: What types of electronic resources are available for users in Kwara State university library?

Table 1: Types of ERs for Users in Kwara State University Library

\begin{tabular}{|l|l|l|}
\hline Electronic Resources & \multicolumn{2}{|c|}{ Response Received } \\
\hline & Available (\%) & Not Available (c) \\
\hline Institutional Repository & $162(47 \%)$ & $183(53 \%)$ \\
\hline E - Journals/ Magazines & $162(47 \%)$ & $183(53 \%)$ \\
\hline E - Newspaper & $254(74 \%)$ & $91(26 \%)$ \\
\hline Online - Databases & $136(39 \%)$ & $209(61 \%)$ \\
\hline CD - ROMS & $125(36 \%)$ & $220(64 \%)$ \\
\hline E - Books & $263(76 \%)$ & $252(24 \%)$ \\
\hline DVD & $90(26 \%)$ & \\
\hline
\end{tabular}




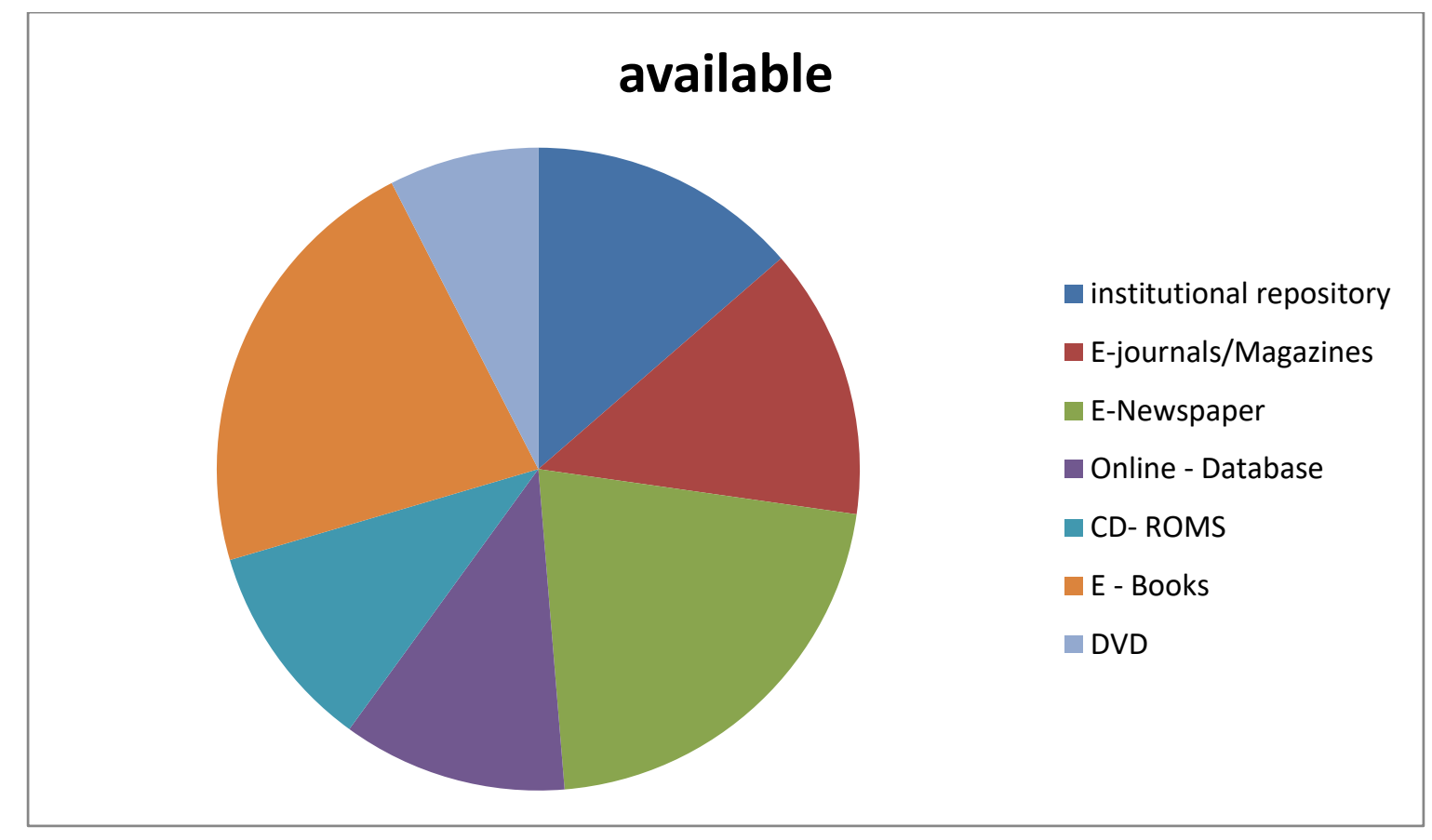

Table 1 presented the types of electronic resources in the Kwara State university library. The Table has shown that electronic books with $76 \%$ have the highest response rate more than any others, E-newspapers have 74\%, Institutional Repository \& E - journals have 47\%, while Bibliographic Databases 39\%, CD - ROMS 36\% and DVD have the lowest response of 26\% respectively. 
Research Question Two: To what extent do the users utilize electronic resources in Kwara State university library?

For convenience and ease of data presentation and analysis, the five points Likert Scale were collapsed to 3 points. They are: Highly Utilize (HU), Rarely Utilize (RU) and Undecided (U). This is presented in table 2 .

Table 2: Extent to which Users Utilized ERs in Kwara State University Library

\begin{tabular}{|l|l|l|l|}
\hline Electronic Resources & \multicolumn{3}{|c|}{ Response Received } \\
\hline & HU (\%) & RU (\%) & U (\%) \\
\hline Institutional Repository & $255(74 \%)$ & $85(25 \%)$ & $5(1 \%)$ \\
\hline E - Journals/ Magazines & $215(62 \%)$ & $110(32 \%)$ & $20(6 \%)$ \\
\hline E - Newspaper & $247(72 \%)$ & $90(26 \%)$ & $8(2 \%)$ \\
\hline Online - Databases & $106(31 \%)$ & $210(61 \%)$ & $29(8 \%)$ \\
\hline CD - ROMS & $95(28 \%)$ & $111(32 \%)$ & $139(40 \%)$ \\
\hline E - Books & $147(43 \%)$ & $188(54 \%)$ & $10(3 \%)$ \\
\hline DVD & $68(20 \%)$ & $97(28 \%)$ & $180(52 \%)$ \\
\hline
\end{tabular}




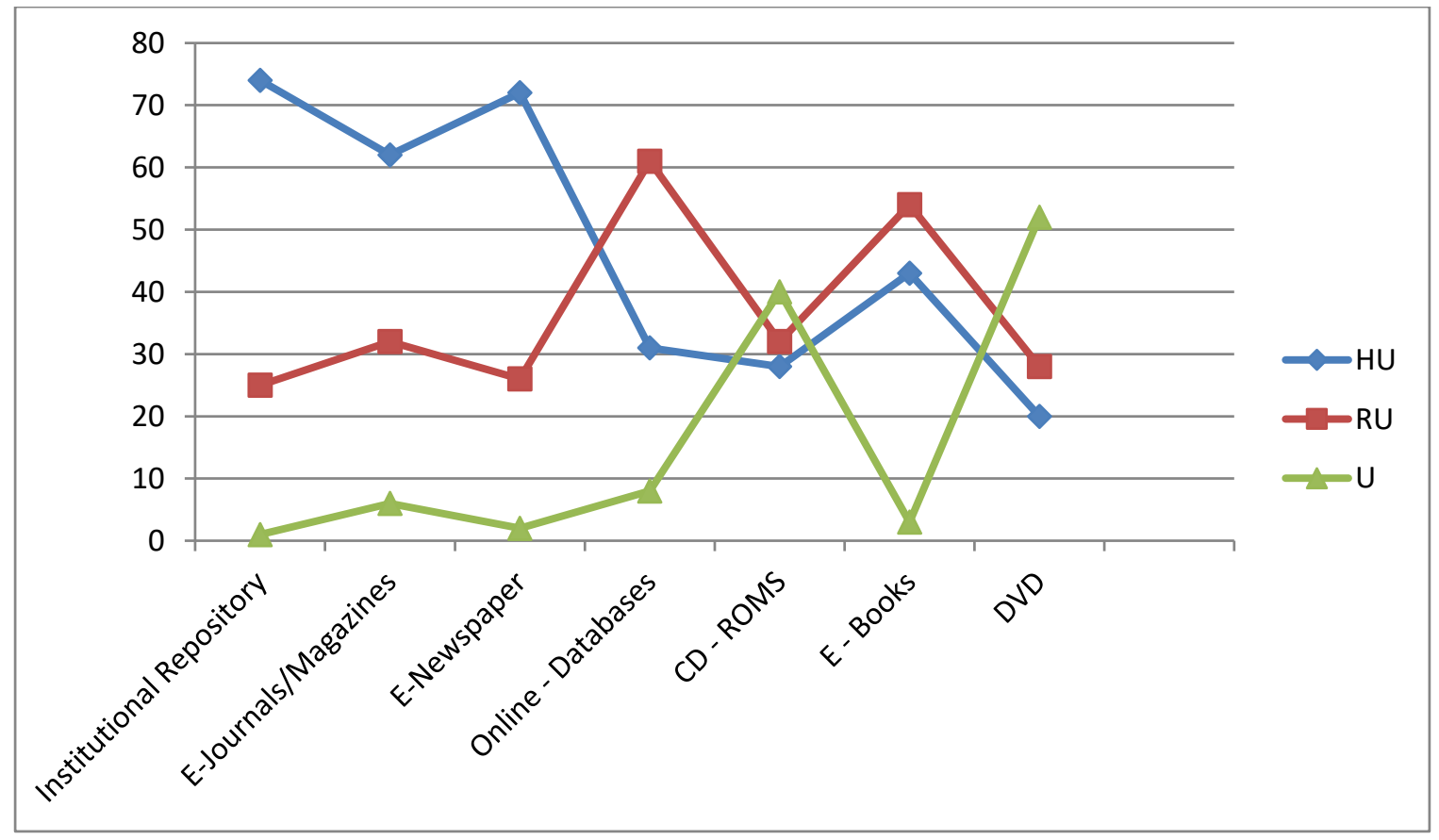

Table 2 indicated that majority of the respondents in Kwara State university library

Indicated that Institutional Repository with the response of $74 \%$ has the highest responses, Enewspaper $72 \%, \mathrm{E}$ - journals/magazines $62 \%$, Online Databases $61 \%$, E - books 54\%, CD ROMS $32 \%$ while DVD with the $28 \%$ have the lowest responses.

From the responses, Institutional Repository with 74\% responses has the highest while DVD has the lowest with $28 \%$ responses.

Research Question Three: What are the challenges faced in accessing electronic resources in Kwara State university library?

Table 3: Challenges Faced in the Utilization of ERs in the Kwara State University Library

\begin{tabular}{|l|l|l|}
\hline Hindrances & Agreed (\%) & Not Agreed (\%) \\
\hline Inadequate computers in the library & $60(17 \%)$ & $285(83 \%)$ \\
\hline Power outages & $290(84 \%)$ & $55(18 \%)$ \\
\hline Insufficient search skills & $203(59 \%)$ & $142(41 \%)$ \\
\hline
\end{tabular}




\begin{tabular}{|l|l|l|}
\hline Poor internet connectivity & $125(36 \%)$ & $220(64 \%)$ \\
\hline Non-availability of required information & $250(72 \%)$ & $95(28 \%)$ \\
\hline Lack of information on how to use E - resources & $235(68 \%)$ & $110(32 \%)$ \\
\hline Limited subscribed titles & $130(38 \%)$ & $215(62 \%)$ \\
\hline
\end{tabular}

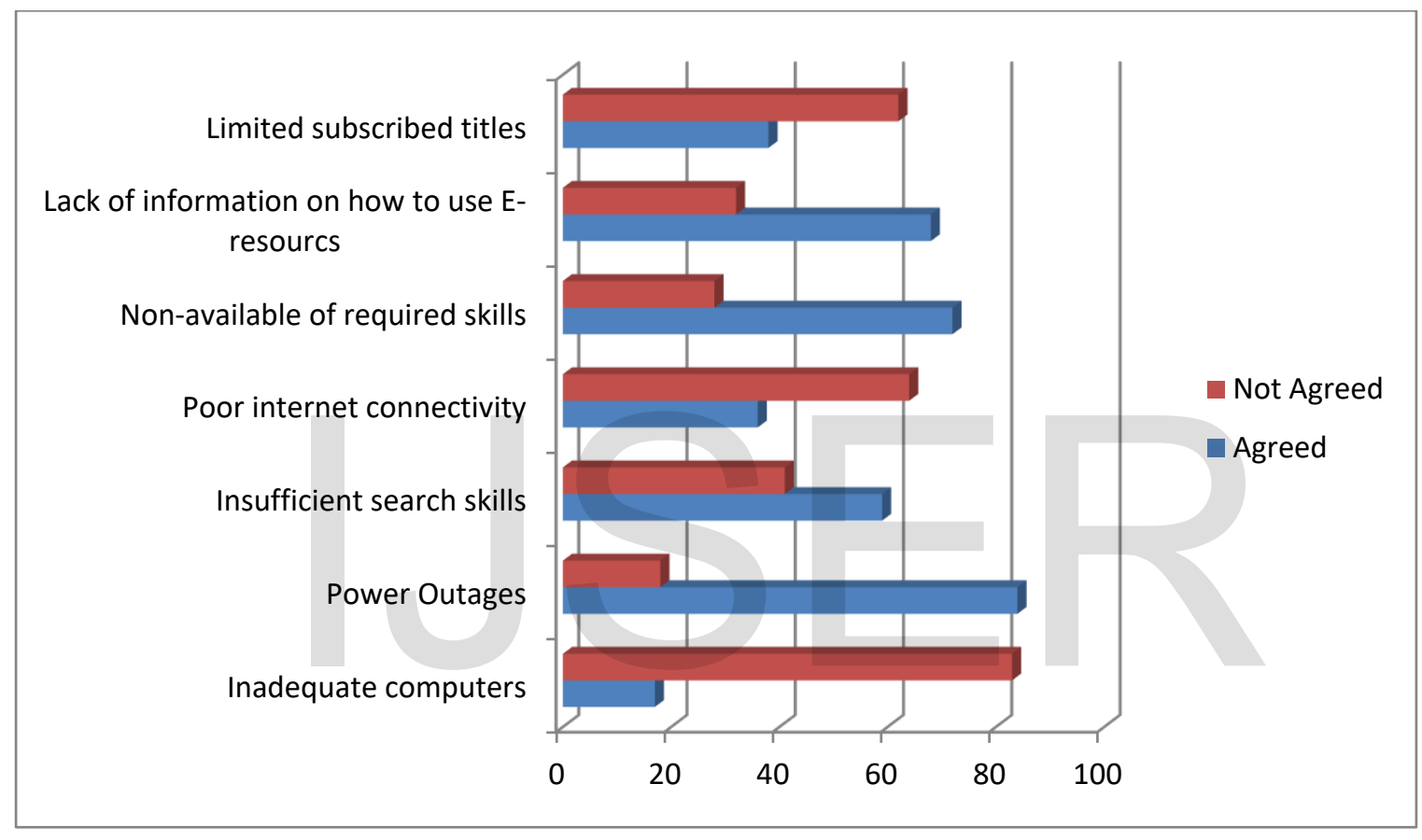

Table 3 indicates that majority of the respondents in Kwara State university library showed that the challenges they encountered the most in accessing electronic resources Power outrage with responses of $84 \%$, non-availability of required information $72 \%$, Lack of information on how to use $\mathrm{E}$ - resources with the responses of $68 \%$, insufficient search skills 59\%, limited subscribed titles $38 \%$, poor internet connectivity $36 \%$ while Inadequate computers in the library with $17 \%$ have the lowest responses.

From the responses angle, power outrages with the $84 \%$ have the highest responses while inadequate computers in the library with the responses of $17 \%$ have the lowest responses. 


\section{Discussion of Findings}

The study revealed that e-books have the highest response rate on the types of e-resources. This finding is in line with the studies of Jonathan and Udo (2015), who found out that e-book, had the highest percentage of the respondents in the south east of Nigerian Federal Universities and University libraries of Adamawa State respectively. The implication of this finding is that, users in the Kwara State university library can access and use electronic resources since it's meant for them.

Institutional repositories were the highly used e-resources. This result is not in agreement with the study of Alhassan and Macaulay (2015) on availability and utilization of electronic resources by university students in Niger State who revealed that electronic journals were highly used by the respondents in the two universities in Niger State. It implies that users in the Kwara State university library used institutional repository the most to get information they required.

The major challenge encountered by users in using e-resources was power outage. This finding is similar to that of Ankrah and Atuase (2018), on the use of e-resources by postgraduate students of the University of Cape Coast, who reported that most of the respondents were of the view that power outages was the major challenge faced in using e-resources. 


\section{CONCLUSION}

The study depicted that the e-resources are extensively accepted among the users of Kwara State university library. Moreover, majority of users are becoming increasingly contingent on these eresources to extract desired information required. It heartening to note that the majority of the users are aware about the resources and services such as availability of Online Databases, CD ROMs, DVD,E - books and E - journals/magazines, Institutional Repository and e - newspaperresources provided by the university library management. It is evident from the above mentioned analysis that the availability of e-resources to support course work and research work for all the existing disciplines in the campus is quite sufficient. Major problem experienced by users is lack power outage to utilize these resources and this one quality may actually be hindering the ability to meet the desideratum of users.

\section{Recommendations}

The followings were recommended in line with the findings:

- Since electronic books are highly available in the university library, the Kwara State university management should create more of other types especially DVD for the users.

- University library personnel should conduct short term training course on ways, means and procedures on how the users can access others e - resources since the institutional repository is highly utilized.

- Kwara State university library management should ensure that power outages as the major challenge is minimized by mounting up inverter and or standby generator to provide 24 hours power supply

- Library management should also provide user training for the advanced use of electronic resource as users independently want to seek a source to gain electronic resources. 
- University must adopt new polices for providing sufficient funds for subscription of eresources.

If such suggestions are considered and implanted quickly, then the situation regarding electronic resources in Kwara State university library would improve considerably.
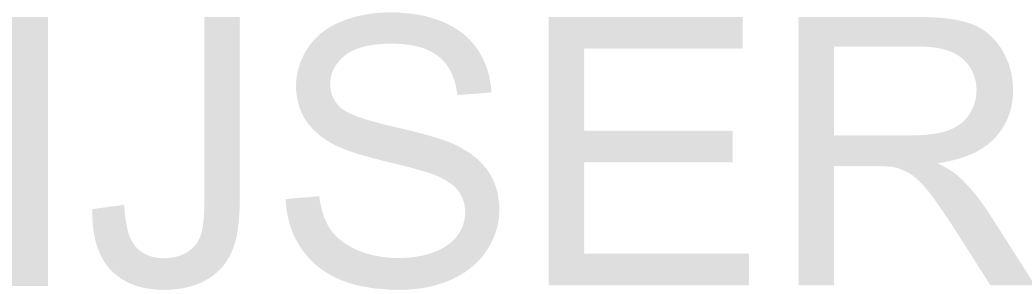


\section{References}

Adeniran, P. (2013). Usage of Electronic Resources by Undergraduates at the Redeemer's

University, Nigeria. International Journal of Library and Information Science, 5(10), 319-324.

Retrieved from http://www.academicjournals.org/IJLIS

Alhassan, J. A. \& Macaulay, S. O. (2015).Availability and Utilization of Electronic Resources by University Students in Niger State. International Conference on 21st Century, 7(1), 10-19.

Alphonce, S. (2015). The use of digital information resources to enhance learning among university students. a case of Teofilo Kisanji University in Tanzania. Masters Dissertation, University of Dar es Salaam.

Ankrah, E. \& Atuase, D. (2018). The use of Electronic Resources by Postgraduate Students of the University of Cape Coast. Library Philosophy and Practice, 1-36. Retrieved from https://digitalcommons.unl.edu/libphilprac/1632

Ansari, M. N., \& Zuberi, B. A. (2010). Use of Electronic Resources among Academics at the University of Karachi, Library Philosophy and Practice, 1-7. Retrieved from http://digitalcommons.unl.edu/libphilprac/385

Atram Ku. P.N. (2017).Digital Library Services in the Digital Age. International Journal of Library \& Information Science (IJLIS). Vol. 6(1), pp. 79-82, Article ID:

IJLIS_06_01_009 Available online at http://www.iaeme.com/IJLIS/issues.asp.

Bajpai, R.P., Hada, K. S. and Bajpai, G. (2016). Academic Libraries and E-Learning: Initiative and Opportunities. International Journal of Library \& Information Science (IJLIS).Vol.

Vol. 5(3), pp. 159-165, Article ID: IJLIS_05_03_015 Available online at http://www.iaeme.com/IJLIS/issues.asp.

Bankole, O. M., Ajiboye, B. A. \&Otunla, A. O. (2015).Use of Electronic Information Resources by Undergraduate of Federal University of Agriculture, Abeokuta, Ogun State, Nigeria.

International Journal of Digital Library Services, 5(4), 1-14. Retrieved from http://www.ijodls.in/uploads/3/6/0/3/3603729/1545.pdf

Baro, E. E., Endouware, B. C. \& Ubogu, J. O. (2011).Awareness and Use of Online Information Resources by Medical Students at Delta State University. Library Hi Tech News, 28(10), 11-17. Bhatt, S. \& Rana, M. S. (2011).E-information usage among engineering academics in India with special reference to Rajasthan State. Library Hi Tech. 29(3), 496-511. 16

Cothran, T. (2011). Google Scholar Acceptance and Use among Graduate Students: A

Quantitative Study. Library and Information Science Research, 33(4), 293-301.

Dar, T. H., Jeelani, S. G. M., Mir H. A. and Ganaie, S. A. (2017). USE OF ICT IN IIT AND

IIM LIBRARIES OF INDIA. International Journal of Library \& Information Science (IJLIS). Vol. 6(1), pp.01-18, Article ID: IJLIS_06_01_001. Available online at http://www.iaeme.com/IJLIS/issues.asp.

Dongardive, P. (2015). Use of Electronic Information Resources at College of Dry Land Agriculture and Natural Resources, Makelle University, Ethiopia. International Journal of Library and Information Science, 7(3), 44-68.

Egberongbe, H. S. (2011). The Use and Impact of Electronic Resources at the University of Lagos. Library Philosophy and Practice. Retrieved from webpages.uidaho.edu/mbolin/egberongbe.html.

Emereole, N \&Ogugua, J. C. (2007). Library Use Pattern in the Federal University of Technology, Owerri: A Survey. Borno Library, Archival and Information Science Journal, 6(1), 49-57. 
Johnson, S., Evensen, O. G., Gelgand, J., Lammers, G., Sipe, L. and Zilper, N. (2012). Key issues for e-resources collection development: a guide for libraries. The Hage, Netherlands: IFLA.

Khan, J. (2016).Awareness and use of digital resources and services in the IIT Delhi Library. International Journal of Research-GRANTHAALAYAN, 4 (6).

Kumar, G.R. (2016). Awareness and use of digital library resources by faculty members of engineering college libraries in Warangal District Telangana: A study. International of research in library science, 2 (2), 188- 200.

Kumar, G. T., \& Kumar, B. T. S. (2008). Use of Electronic Information Sources by the Academic Community: A Comparative Study, 6th International CALIBER- University of Allahabad. Allahabad, 2(4), 684-692.

Kwafoa, P. N., Osman, I \&Afful-Arthur, P. (2014). Assessment of the Use of Electronic Resources Among Administrators And Faculty In The University of Cape Coast. Library Philosophy and Practice, 1-19

Israel, O. and Edesiriu, O. (2017). Undergraduates' Computer Skills and the Use of Online Information Resources: A Case Study of Library and Information Science Students of Delta State University, Nigeria. International Journal of Academic Library and Information Science. Vol. 4(3), pp. 87-93. ISSN: 2360-7858. http://www.academicresearchjournals.org/IJALIS/Index.htm. Makerere students in Uganda. Evidenced Based Library and Information Practice, 3(3). Retrieved from http;//creative commons.org/licenses/by/2-0. Minčić-Obradović, K. (2011). E-books in academic libraries. Oxford: Chandos. Msagati, N. (2014). Awareness and Use of Scholarly Electronic Journals by Members of Academic Staff: A Case Study of Dares Salaam University College of Education (DUCE). Library Philosophy and Practice, paper no.1124 Mollel, M.M. (2016). Users' attitude towards the utilization of electronic resources at the Institute of Finance Management, Dar es Salaam, Tanzania.Masters Dissertation, University of Dar es Salaam.

Nnadozie, C.O. and Nwosu C. C. (2016). Analysis of Final Year Students' Satisfaction with Information Resources and Services in Four Nigerian Federal University Libraries.

International Journal of Advanced Library and Information Science. Cloud Publications. Okezie, C. A. and Onyekweodiri, N. E. (2016). An Evaluation of Relevance of Library and Information Science Publications of Librarians in South-East Nigeria: 2002 - 2012 in Focus. International Journal of Library \& Information Science (IJLIS). Vol. 5(3), pp. 2433, Article ID: IJLIS_05_03_003. Available online at http://www.iaeme.com/IJLIS/issues.asp.

Vol. 4(1), pp. 333-345, Article ID Sci-385.ISSN 2348-5167. http://scientific.cloudjournals. com/index.php/IJALIS/article/view/Sci-385.

Okello-Obura, C. \& Magara, E. (2008).Electronic information access and utilization by Okiki C. O. (2012). Electronic information resources awareness attitudes and use by academic staff of members of university of Lagos, Nigeria. Library Philosophy and P(e-journal), paper no. 834. Oyedapo, R. O. \&Ojo, R. A. (2013).A Survey of the Use of Electronic Resources in Hezekiah Oluwasan Library, Obafemi Awolo University, Ile-Ife, Nigeria. Library Philosophy and Practice. Retrieved from http://digitalcommons.unl.edu/libphilprac/884 17

Singh, V. (2013). Use of e-resources by faculty members and research scholars of department of computer sciences and mathematics of Jamia Millia Islamia University, Delhi: A study. Library Progress (International), 33 (2), 235-250. 
Prakash, I. N., (2017). Resource Sharing: A Library Perceptive. International Journal of Library \& Information Science (IJLIS). Vol. 6(1), pp. 19-22, Article ID:

IJLIS_06_01_002 Available online at http://www.iaeme.com/IJLIS/issues.asp.

Saikia, M. and Gohain, A. (2013). "Use and User's Satisfaction on Library Resources and Services in Tezpur University (India): a study" Library Philosophy and Practice (ejournal). Paper 972. http://digitalcommons.unl.edu/libphilprac/972.

Al - Suqri, Lillard\& Al - Saleem (2014).Information Access and Library Users Needs in Developing Countries.Premier reference source 116, 125.

Ukachi, N. B. (2013). Accessibility and Students Variables as Correlates of the Use of Electronic Information Resources in University Libraries in South-West, Nigeria.Nsukka: Department of Library and Information Science (Unpublished Theses)

Uplaonkar, Shilpa and Keshva (2013). Use of electronic information resources and services in S. Nijalingappa medical College: A study. Library Progress (International),33(1), 1-11.

Verma, M.K., \&Laltlanmawii, R. (2016). Use of library collections and services by faculties and research scholars of school of physical sciences, Assam University, Silchar: a study.

Yakubu, H. \&Olatoye, O. O. (2015). Use of Electronic Resources in Teaching and Learning at Federal University Dutsinma, Nigeria.Mediterranean Journal of Social Science, 6(1), 584-592. View publication.

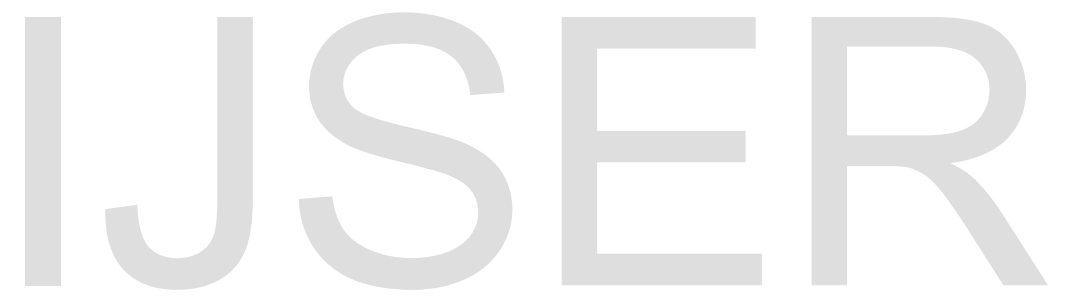

